Hydrology, environment

\title{
Mineralogical and geochemical study of clay and calcite veins in a shear zone related to a sulphur spring (NW Portugal)
}

\section{Étude minéralogique et géochimique de veines d'argile et de calcite dans une zone de cisaillement concernant une source sulfureuse}

\author{
Manuela Fonte Lima, Jorge Pamplona, Maria Amália Sequeira Braga* \\ Centro de Investigação Geológica, Ordenamento e Valorização de Recursos (CIG-R), Departamento de Ciências da Terra, Universidade do Minho, Campus de Gualtar, \\ 4710-057 Braga, Portugal
}

\section{A R T I C L E I N F O}

\section{Article history:}

Received 25 February 2011

Accepted after revision 24 May 2011

Presented by Ghislain de Marsily

\section{Keywords:}

Fracture infillings

Granite weathering

Calcite

Smectite

Isotopic signatures

Sulphur spring

Water-rock interaction

Portugal

\section{Mots clés :}

Remplissage de fractures

Altération du granite

Calcite

Smectite

Signatures isotopiques

Source sulfureuse

Interaction eau-roche

Portugal

\begin{abstract}
A B S T R A C T
In the Terras de Bouro area, in Northwest Portugal, the role of water-rock interaction, either by the mineralization of the sulphur spring, or by the nature of the granite secondary minerals, was studied as a complement to exploration for mineral water. This approach is justified by the peculiar mineral paragenesis found, which is very different from those of the regional weathering products. Calcite and montmorillonite as veins infilling and pyrite in the wall rock are the secondary minerals characteristic of mineral water occurrence. Sulphur water composition, alkaline $\mathrm{pH}$ and low redox potential are some factors that may favour the formation of montmorillonite, calcite and essentially pyrite, in the spring zone. Isotopic signatures in $\delta^{2} \mathrm{H}$ and $\delta^{18} \mathrm{O}$ of sulphur water show that its origin is dominantly meteoric. Isotopic signatures $\delta^{13} \mathrm{C}$ and $\delta^{18} \mathrm{O}$ of calcite and of the inorganic carbon in the water suggest that calcite precipitates from carbonate species in the sulphur water at $\sim 17^{\circ} \mathrm{C}$.
\end{abstract}

(c) 2011 Académie des sciences. Published by Elsevier Masson SAS. All rights reserved.

R É S U M É

Dans la région de Terras de Bouro (Nord-Ouest Portugal), le rôle de l'interaction eau-roche, soit par la minéralisation de la source sulfureuse, soit par la nature des minéraux secondaires, a été étudié à la suite des travaux d'exploitation des eaux minérales. Cette démarche est justifiée par une paragenèse minérale particulière, laquelle est très différente de celle des produits d'altération météorique régionaux. La calcite et la montmorillonite en tant que remplissage des veines et la pyrite dans l'encaissant sont les minéraux secondaires caractéristiques du site d'occurrence de l'eau minérale. La composition de l'eau sulfureuse, son pH élevé et un bas potentiel redox sont des facteurs qui expliquent la formation, dans la zone d'émergence, de montmorillonite, calcite et particulièrement de pyrite. La signature isotopique $\delta^{2} \mathrm{H}$ et $\delta^{18} \mathrm{O}$ de l'eau sulfureuse montre une origine météorique dominante. Les analyses isotopiques $\left(\delta^{13} \mathrm{C}\right.$ et $\left.\delta^{18} \mathrm{O}\right)$ des espèces carbonatées de l'eau et des calcites suggèrent que la calcite a précipité à partir de cette eau dans les conditions de l'émergence $\left(\sim 17^{\circ} \mathrm{C}\right)$.

(c) 2011 Académie des sciences. Publié par Elsevier Masson SAS. Tous droits réservés.

\footnotetext{
* Corresponding author.

E-mail address: masbraga@dct.uminho.pt (M.A.S. Braga).
} 